U.S. DEPARTMENT OF THE INTERIOR

U.S. GEOLOGICAL SUR VEY

\title{
PICTORIAL MAP AND CONTROLLED PHOTOMOSAIC OF TETHYS
}

Prepared for the

NATIONAL AERONAUTICS AND SPACE ADMINISTRATION

MISCELLANEOUS INVESTIGATIONS SERIES

Published by the U.S. Geological Survey, 1992 